\title{
Mediacje w sprawach rodzinnych
}

Jedną z form pomocy skierowaną do rodzin uwikłanych w konflikt są mediacje. Należą one do pozasądowych sposobów rozwiązywania sporów i umożliwiają polubowne rozwiązanie trudnej sprawy przy wsparciu bezstronnej i neutralnej osoby trzeciej. Dzięki mediacji członkowie rodziny mogą samodzielnie wypracować wzajemnie satysfakcjonujące i konstruktywne rozwiązanie problemu, a także, co jest szczególnie ważne w przypadku członków rodziny, zachować wzajemne poprawne relacje. Mediacje stwarzają bowiem okazję do wysłuchania drugiej osoby i zrozumienia jej potrzeb. Umożliwiają wzajemną komunikację w atmosferze szacunku i otwartości na dialog. Christopher Moore podkreśla dwojakie korzyści związane z mediacjami, gdyż dzięki nim strony mogą nie tylko rozwiązać konkretny konflikt, ale także ustanowić lub wzmocnić relacje oparte na wzajemnym zaufaniu i szacunku lub też je zakończyć, ale w sposób, który minimalizuje koszty emocjonalne i straty psychiczne ${ }^{1}$. W przypadku mediacji rodzinnych szczególnie wart podkreślenia wydaje się zwłaszcza aspekt relacyjny, gdyż od wzajemnych ustaleń stron nie tylko zależeć będzie rozwiązanie konkretnej spornej sprawy, ale także sam sposób tego ustalenia może rzutować na

1 Ch. Moore, Mediacje. Praktyczne strategie rozwiązywania konfliktów, tłum. A. Cybulko, M. Zieliński, Warszawa 2009, s. 30. 
kształtowanie się relacji rodzinnych w przyszłości. Mediacje mogą być zatem szczególnie przydatne w sytuacji rozwodu dla uzgodnienia obopólnie korzystnych warunków porozumienia np. w kwestii opieki, wychowania i kontaktów z dzieckiem po rozwodzie, na co, w kontekście dobra dziecka, zwraca uwagę Rzecznik Praw Dziecka².

Mediacje są rekomendowanym przez Radę Europy sposobem rozwiązywania konfliktów rodzinnych, gdyż przyczyniają się do poprawy komunikacji między członkami rodziny i obniżenia poziomu konfliktu, a także sprzyjają osiągnięciu polubownego rozwiązania. Są pomocne dla zapewnienia ciągłości kontaktów rodziców i dzieci. Mediacje prowadzone w związku z rozwodem przekładają się na zmniejszenie społecznych i ekonomicznych kosztów rozwodu ponoszonych przez strony i państwo. Mediacje rodzinne to wreszcie skrócenie czasu, który w innym przypadku byłby niezbędny do rozwiązania konfliktu³.

\section{Specyfika mediacji rodzinnych}

Mediacje to sposób rozwiązywania konfliktu, który opiera się na niewładczej ingerencji w konflikt neutralnej i bezstronnej osoby trzeciej ${ }^{4}$. Stanowią one dobrowolne, poufne i niesformalizowane postępowanie pozasądowe, w którym uczestniczą skonfliktowane strony i mediator, a którego celem jest doprowadzenie do ugodowego rozwiązania sporu ${ }^{5}$. W Rekomendacji Rady Europy Nr R (98) 1 mediacja określana jest jako „proces, w którym trzecia strona, niezaangażowana w sprawy będące przedmiotem konfliktu, ułatwia dyskusję między stronami, pomagając im rozwiązać problemy i dojść do porozumienia”. Jednym z rodzajów mediacji są mediacje ro-

2 M. Michalak, Mediacja a dziecko, w: Mediacja dla każdego, red. L. Mazowiecka, Warszawa 2010, s. 118-119.

$3 \quad$ Pkt 7 Rekomendacji Nr R (98) 1 Komitetu Ministrów Rady Europy dla państw członkowskich na temat mediacji rodzinnej oraz Memorandum wyjaśniające (przyjęta przez Komitet Ministrów 21 stycznia 1998 roku na 616-tym spotkaniu wiceministrów, https:// www.ms.gov.pl/pl/dzialalnosc/mediacje/publikacje-akty-prawne-statystyki/ (10.10.2018).

4 A. Kalisz, A. Zienkiewicz, Mediacja sądowa i pozasądowa. Zarys wykładu, Warszawa 2009, s. 43.

$5 \quad$ Czy tylko sad rozstrzygnie w sporze? Mediacja i sądownictwo polubowne. Informator o alternatywnych sposobach rozwiązywania sporów, red. A. Rękas, Warszawa 2010, s. 19.

$6 \quad$ Pkt 16 Rekomendacji Nr R (98) 1..., dok. cyt. 
dzinne. Według Agaty Gójskiej są one „procedurą rozwiązywania konfliktu, w której bezstronna i neutralna trzecia strona towarzyszy członkom rodziny w procesie uzgodnień, pomagając w zdefiniowaniu kwestii spornych, określeniu potrzeb i interesów stron oraz, o ile taka ich wola, wypracowaniu wzajemnie satysfakcjonującego oraz świadomego porozumienia"7. Mediacje rodzinne skupiają się na „pomocy członkom rodziny w uporządkowaniu spraw spornych i wypracowaniu rozwiązań, akceptowanych przez wszystkie

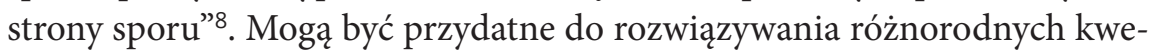
stii związanych z organizacją życia rodzinnego ${ }^{9}$.

Mediacje w sprawach rodzinnych odbywają się w gronie rodzinnym $\mathrm{i}$ biorą $\mathrm{w}$ nich udział: małżonkowie, rodzeństwo, rodzice, dzieci, dalsi członkowie rodziny. Mediacje rodzinne dotyczą także partnerów żyjących w związkach nieformalnych ${ }^{10}$. Zakres spraw będących przedmiotem mediacji jest bardzo szeroki i nie ogranicza się wyłącznie do ustaleń okołorozwodowych. Oprócz separacji i rozwodu małżonków, w tym spraw związanych z warunkami rozstania, uregulowania opieki nad dziećmi, ustalenia kontaktów z dzieckiem, alimentów czy podziału majątku ${ }^{11}$, mediacja może dotyczyć: kontraktów przedślubnych (np. uregulowania kwestii finansowych i majątkowych, ustalenia miejsca zamieszkania po ślubie, religii przyszłych dzieci), konfliktów w rodzinach zrekonstruowanych (np. związanych $\mathrm{z}$ relacjami małżeńskimi, sprawami finansowymi, relacjami z dziećmi, relacji dzieci-nowi partnerzy rodziców, kontaktami dzieci z dziadkami), spraw związanych z opieką nad osobami starszymi i chorymi oraz spraw odnoszących się do adopcji (sytuacja rodziców biologicznych i rodziców adopcyjnych, kontakty rodzice-dziecko) ${ }^{12}$. Z mediacji można skorzystać w sporach dotyczących gospodarowania wspólną własnością, podziału rodzinnego majątku bądź spadku, zasad korzystania ze wspólnego mieszkania czy w sytuacji konfliktu dotyczącego rodzinnego przedsiębiorstwa. Mediacje mogą

\footnotetext{
A. Gójska, Mediacje rodzinne, Warszawa 2014, s. 30-31.

8 H. Przybyła-Basista, Mediacje rodzinne w konflikcie rozwodowym. Gotowość i opór małżonków a efektywność procesu mediacji, Katowice 2006, s. 18.

9 K. Bargiel-Matusiewicz, Negocjacje i mediacje, wyd. II zmienione, Warszawa 2010, s. 103 .

A. Cybulko, Mediacja w sprawach rodzinnych, w: Mediacje. Teoria i praktyka, red. E. Gmurzyńska, R. Morek, Warszawa 2009, s. 193.

11 K. Bargiel-Matusiewicz, Negocjacje i mediacje, s. 105; H. Przybyła-Basista, Mediacje rodzinne..., dz. cyt., s. 20; Czy tylko sąd rozstrzygnie..., dz. cyt., s. 39-40.

12 H. Przybyła-Basista, Mediacje rodzinne..., dz. cyt., s. 21-22.
} 
być także prowadzone w sporach dwunarodowościowych rodzin ${ }^{13}$. Z praktyki mediatorów rodzinnych wynika ponadto, że do mediacji kierowane są również sprawy rodzinne o podłożu karnym, dotyczące fizycznego i psychicznego znęcania się nad osobami najbliższymi oraz związane z groźbami karalnymi, uporczywym nękaniem, naruszeniem czynności narządu ciała i rozstroju zdrowia ${ }^{14}$.

Wykorzystywanie mediacji jako ugodowego i pozasądowego sposobu rozwiązywania konfliktów, w tym sporów rodzinnych, ma swoją długą historię. Stanisław Kordasiewicz zwraca uwagę na porozumienia w sprawach rodzinnych spisywane na papirusach w VI wieku n.e. w starożytnym Egipcie, a dotyczące m.in. spadku i podziału gruntu ornego. Ugoda pozwalała na szybkie zakończenie konfliktu, czego skutkiem było przygotowanie $\mathrm{w}$ odpowiednim czasie gruntu pod uprawy i uzyskanie plonów ${ }^{15}$. Jak pisze autor, „sprawy takie, ze względu na bliskie i długotrwałe relacje między stronami, sprzyjały poszukiwaniu rozwiązań polubownych"16. W Europie mediacje wykorzystywane były w konfliktach między panującymi dynastia$\mathrm{mi}$ i w rodzinach arystokratycznych ${ }^{17}$. Rozwiązywanie sporów rodzinnych przy udziale mediatora praktykowane było również przez stulecia $\mathrm{w}$ społecznościach żydowskich, w krajach arabskich i azjatyckich oraz na kontynencie amerykańskim ${ }^{18}$. Także współcześnie mediacje wykorzystywane są do polubownego rozwiązywania konfliktów rodzinnych. W Stanach Zjednoczonych zaczęto je stosować w latach 70 . XX wieku, choć nieformalnie praktykowane były już dekadę wcześniej. W 1981 roku w stanie Kalifornia wprowadzono obligatoryjne mediacje w sprawach rodzinnych ${ }^{19}$. Jak wskazuje Christopher Moore, w Ameryce Północnej mediacje rodzinne należą do najszybciej rozwijających się obszarów mediacji. Są prowadzone w sprawach rozwodowych oraz w kwestiach opieki nad dziećmi i ich ochrony, a także w konfliktach na tle adopcji i odebrania praw rodzicielskich oraz

\footnotetext{
13 Czy tylko sąd rozstrzygnie..., dz. cyt., s. 43-45, 49-52.

14 M. Kaźmierczak, J. Kaźmierczak, Mediacja rodzinna. Praktyczny poradnik, Warszawa 2015, s. 31.

15 S. Kordasiewicz, Historyczna i międzynarodowa perspektywa mediacji, w: Mediacje. Teoria i praktyka, dz. cyt., Warszawa 2009, s. 32-34.

16 S. Kordasiewicz, Historyczna i międzynarodowa..., dz. cyt., s. 34.

17 S. Kordasiewicz, Historyczna i międzynarodowa..., dz. cyt., s. 41.

18 S. Kordasiewicz, Historyczna i międzynarodowa..., dz. cyt., s. 36-40; Ch. Moore, Mediacje..., dz. cyt., s. 35-37.

19 H. Przybyła-Basista, Mediacje rodzinne..., dz. cyt., s. 39-40.
} 
w sytuacji sporów domowych z użyciem przemocy. Mediacje stosowane są także w sprawach związanych z separacją par osób tej samej płci. Mediacje praktykowane są tam zarówno jako obligatoryjne programy sądowe, które muszą poprzedzić rozpatrzenie sprawy przed sądem, jak również jako dobrowolne programy sądowe bądź mediacje prywatne, prowadzone przez samodzielnych mediatorów, spółki mediacyjne czy organizacje spoleczne ${ }^{20}$. W krajach europejskich mediacje w sprawach rodzinnych zaczęly się rozwijać w latach 70. XX wieku. Krajem, który jako pierwszy (w 1971 roku) wprowadził je do swojego systemu prawnego, była Wielka Brytania $^{21}$. Korzystając $\mathrm{z}$ doświadczeń amerykańskich oraz brytyjskich $\mathrm{w}$ zakresie mediacji, dwie dekady później wiele krajów znowelizowało własne kodeksy rodzinne, przyczyniając się do rozwoju mediacji w obszarze spraw rodzinnych ${ }^{22}$. W krajach Europy Zachodniej mediacje rodzinne rozwinęly się w Irlandii, Niderlandach, Niemczech, Francji i krajach skandynawskich oraz w krajach Europy Wschodniej: Bułgarii, Czechach, Macedonii, Rosji, Słowacji i na Ukrainie oraz na Węgrzech ${ }^{23}$. Ugodowy sposób rozwiązywania sporów rodzinnych poprzez mediację praktykowany jest także $\mathrm{w}$ wielu krajach pozaeuropejskich. Jako przykłady takich krajów Moore podaje Chiny, Japonię (z obowiązkowymi mediacjami w większości postępowań rozwodowych i w sprawach opiekuńczych), Hong Kong, Singapur, Koreę, Indie, Nepal, Pakistan, Bangladesz, Palestynę, Izrael, Argentynę oraz Australię i Nową Zelandię ${ }^{24}$.

W Polsce mediacje rodzinne zaczęly się rozwijać w latach 90 . XX wieku wraz z powstaniem pierwszych ośrodków mediacyjnych i programów szkolenia mediatorów. Na przełomie XX i XXI wieku mediacje rodzinne prowadziły już coraz liczniejsze ośrodki pozarządowe w ramach publicznych poradni rodzinnych i rodzinnych ośrodków diagnostyczno-konsultacyjnych ${ }^{25}$. Prace nad zmianami legislacyjnymi, które umożliwiłyby prowadzenie mediacji w sprawach rodzinnych oraz wypracowanie standardów szkoleniowych dla mediatorów rodzinnych, rozpoczęto w czerwcu 2001

\footnotetext{
20 Ch. Moore, Mediacje..., dz. cyt., s. 41.

21 H. Przybyła-Basista, Mediacje rodzinne..., dz. cyt., s. 34.

22 H. Przybyła-Basista, Mediacje rodzinne..., dz. cyt., s. 32-34, 42-43.

23 Ch. Moore, Mediacje..., dz. cyt., s. 54.

24 Ch. Moore, Mediacje..., dz. cyt., s. 48-54.

25 U. Gruca-Miąsik, Negocjacje i mediacje w kregu pomocy, wychowania i prawa, Rzeszów 2011, s. 69.
} 
roku wraz z powołaniem przy Ministrze Sprawiedliwości Zespołu Pilotażowego ds. Mediacji Rodzinnej, w skład którego weszli przedstawiciele Ministerstwa, sędziowie oraz mediatorzy ${ }^{26}$. Mediacje w sprawach rodzinnych zostały wprowadzone do polskiego systemu prawnego cztery lata później na podstawie nowelizacji Kodeksu postępowania cywilnego z dnia 28 lipca 2005 r., która weszła w życie 10 grudnia 2005 roku. Z danych Ministerstwa Sprawiedliwości wynika, że rokrocznie wzrasta liczba mediacji prowadzonych w sporach rodzinnych. W latach 2006-2017 widoczny jest wzrost liczby ugód zawieranych w wyniku mediacji rodzinnych, choć równocześnie wiele sporów rodzinnych nie zostaje rozwiązanych na drodze porozumienia mediacyjnego. Najczęściej ugody zawierane są w kwestii kontaktów z dzieckiem, wysokości alimentów, miejsca zamieszkania nieletniego oraz sposobu wykonywania władzy rodzicielskiej. Najrzadziej prowadzone są mediacje w trybie Konwencji haskiej z 1980 roku, dotyczące rodzicielskiego uprowadzenia dziecka ${ }^{27}$.

Mediacje w sprawach rodzinnych mogą być prowadzone na postawie postanowienia sądu kierującego strony do mediacji (mediacja sądowa) lub na podstawie umowy o mediację (mediacja umowna). Jak wskazuje Anna Cybulko, z mediacji umownych korzystają często skłóceni małżonkowie, którzy traktują mediację jako ostatnią szansę na rozwiązanie problemów czy dojście do porozumienia lub też w sytuacji zagrożenia rozpadem małżeństwa. Do umownych mediacji zgłaszają się także małżonkowie, którzy postanowili się rozwieść i chcą wcześniej ustalić wszystkie istotne dla nich kwestie ${ }^{28}$. Sąd może skierować strony do mediacji, jeśli istnieją widoki na utrzymanie małżeństwa (art. $436 \$ 1$ k.p.c.) oraz w celu pojednania małżonków (art. $436 \$ 2$ k.p.c.). Mediacja ze skierowania sądu może odbywać się na każdym etapie sprawy o rozwód lub separację. Zgodnie $\mathrm{z}$ art. $445^{2}$ k.p.c. w tym przypadku celem mediacji ma być ugodowe załatwienie spornych kwestii dotyczących zaspokojenia potrzeb rodziny, alimentów, sposobu sprawowania władzy rodzicielskiej, kontaktów z dziećmi oraz spraw majątkowych podlegających rozstrzygnięciu w wyroku orzekającym rozwód lub separację.

26 H. Przybyła-Basista, Mediacje rodzinne..., dz. cyt., s. 47; U. Gruca-Miąsik, Negocjacje i mediacje..., dz. cyt., s. 69.

27 Ministerstwo Sprawiedliwości, Postępowania $w$ sprawach rodzinnych $w$ sądach powszechnych zakończone $w$ wyniku postępowania mediacyjnego w latach 2006-2017, http:// isws.ms.gov.pl/pl/baza-statystyczna/opracowania-wieloletne/ (02.10.2018).

28 A. Cybulko, Mediacja w sprawach rodzinnych, dz. cyt., s. 194. 
Mediacja może być szczególnie przydatna do konstruktywnego wypracowania zasad współpracy rodziców po rozwodzie w postaci zgodnego z dobrem dziecka „porozumienia o sposobie wykonywania władzy rodzicielskiej i utrzymywaniu kontaktów z dzieckiem” (art. 58\$1 i 107\$1 Kodeksu rodzinnego i opiekuńczego). Narzędziem, które umożliwia wypracowanie $\mathrm{w}$ trakcie mediacji wzajemnie satysfakcjonującego porozumienia, jest Rodzicielski Plan Wychowawczy, odnoszący się do takich kwestii, jak:

- sposób wykonywania władzy rodzicielskiej;

- kontakty z dzieckiem - miejsce pobytu i miejsce zamieszkania dziecka, czas i miejsce przebywania dziecka z każdym z rodziców, sposób utrzymywania kontaktów dziecka z osobami trzecimi, np. dalszą rodziną, nowymi partnerami rodziców, czas i miejsce przebywania dziecka z każdym z rodziców w okresie wakacji oraz świąt, ustalenia dotyczące wyjazdów zagranicznych dziecka;

- edukacja szkolna i pozalekcyjna dziecka oraz podział środków finansowych przeznaczanych na te cele;

- sposób podejmowania decyzji związanych ze zdrowiem dziecka i leczenia w przypadku choroby;

- sprawy finansowe - podział kosztów utrzymania i wychowania dziecka, alimenty;

- sposób kontaktowania się rodziców w celu wprowadzenia zmian do poczynionych wcześniej ustaleń ${ }^{29}$.

W literaturze przedmiotu wskazywane są jednak sytuacje, w których mediacja rodzinna nie powinna być prowadzona lub też jej celowość mediator i strony winny szczególnie starannie omówić. Wśród przeciwwskazań wymieniane są: cierpienie przez którąkolwiek ze stron na zaburzenia psychiczne, uzależnienie strony lub stron od alkoholu, narkotyków bądź substancji psychoaktywnych, gdy w rodzinie miała lub ma miejsce przemoc domowa oraz gdy występuje znacząca nierównowaga sił między stronami $\mathrm{i}$ istnieje prawdopodobieństwo, że rozwiązanie może nie być korzystne dla jednej ze stron ${ }^{30}$. Hanna Przybyła-Basista zwraca uwagę, że prowadzenie mediacji w sytuacji występowania przemocy w rodzinie dzieli środowisko mediatorów. Dominujące jest przekonanie, że przemoc domowa jest prze-

29 Centrum Mediacji Partners Polska, Rodzicielski Plan Wychowawczy. Porozumienie rozstających się rodziców, Warszawa 2009, s. 4-9; Czy tylko sąd rozstrzygnie..., dz. cyt., s. 4243.

30 Czy tylko sąd rozstrzygnie..., dz. cyt., s. 45-46. 
ciwskazaniem do prowadzenia mediacji, gdyż jej występowanie rodzi trudność przede wszystkim z zapewnieniem równej pozycji negocjacyjnej stron. Niektórzy mediatorzy uważają, że można stosować mediację w tej sytuacji, jednak z zachowaniem odpowiednich procedur ${ }^{31}$. Dodatkowo mediacja może być niewskazana, gdy stronie lub stronom towarzyszą silne emocje bądź niedawne traumatyczne przeżycia, które utrudniają świadomy i racjonalny osąd oraz skupienie się na przeszłości, co ma miejsce np. w pierwszym etapie emocjonalnego rozstania. W tej sytuacji proponowane jest odłożenie mediacji w czasie, a mediator może zasugerować stronom skorzystanie w tym okresie ze specjalistycznej pomocy terapeutycznej ${ }^{32}$. Agata Gójska zwraca także uwagę, że mediacja może być niewskazana, gdy strony mają rozbieżne oczekiwania wobec mediacji związane z odmiennymi motywacjami przystąpienia do mediacji, a także w rodzinach, w których istnieją dysfunkcjonalne wzorce interakcji ${ }^{33}$.

Standardy prowadzenia mediacji i postępowania mediatora wyróżniają także powody, dla których mediator może przerwać lub zakończyć mediację. Należą do nich sytuacje: gdy strona nie może efektywnie uczestniczyć w mediacji z powodu swego stanu fizycznego lub psychicznego, gdyż np. jest pod wpływem alkoholu lub środków odurzających, gdy strony chcą zawrzeć porozumienie, którego skutków nie są świadome, lub gdy używają mediacji do osiągnięcia nieuczciwych korzyści, a także gdy mediator nabiera przekonania, że traci bezstronność. Mediator może przerwać mediację w sytuacji, gdy jest przekonany, że nie jest możliwe osiągnięcie porozumienia, gdy w jego ocenie uczestnicy osiągnęli impas, którego nie można pokonać i dalsza dyskusja jest nieproduktywna, oraz gdy strony nie mogą uczestniczyć w mediacji, nie są zdolne do mediacji lub nie chcą uczestniczyć w mediacji w autentyczny i zaangażowany sposób ${ }^{34}$.

\footnotetext{
31 H. Przybyła-Basista, Mediacje rodzinne..., dz. cyt., s. 22-24; A. Gójska, Mediacje rodzinne, dz. cyt., s. 171-182.

32 A. Gójska, Mediacja w sprawach rodzinnych. Stan prawny na 1 września 2011 r., Ministerstwo Sprawiedliwości, Warszawa 2011, s. 8; A. Gójska, Mediacje rodzinne, dz. cyt., s. 43.

33 A. Gójska, Mediacje rodzinne, dz. cyt., s. 43-45.

34 Standard VIII, Standardy prowadzenia mediacji i postępowania mediatora, uchwalone przez Społeczną Radę do spraw Alternatywnych Metod Rozwiązywania Konfliktów i Sporów przy Ministrze Sprawiedliwości w dniu 26 czerwca 2006 r., https://www.ms.gov.pl/pl/dzialalnosc/mediacje/publikacje-akty-prawne-statystyki/ (10.10.2018).
} 


\section{Osoba mediatora i zasady mediacji}

Zgodnie $\mathrm{z}$ art. 10 k.p.c. w sprawach, w których dopuszczalne jest zawarcie ugody, strony mogą polubownie rozwiązać konflikt poprzez mediację. Mediatorem może być osoba fizyczna, która ma pełną zdolność do czynności prawnych, korzysta w pełni z praw publicznych (art. $183^{2} \$ 1$ k.p.c.) oraz nie jest sędzią, z wyjątkiem sędziów w stanie spoczynku (art. $183^{2} \$ 2$ k.p.c.). Dodatkowe wymogi odnoszą się do stałych mediatorów, którzy zgodnie $\mathrm{z}$ art. 157a ustawy Prawo o ustroju sądów powszechnych muszą mieć wiedzę i umiejętności w zakresie prowadzenia mediacji, ukończone 26 lat, znać język polski, nie być prawomocnie skazanym za umyślne przestępstwo lub umyślne przestępstwo skarbowe oraz zostać wpisani na listę stałych mediatorów prowadzoną przez prezesa sądu okręgowego. Z uwagi na szczególny aspekt mediacji rodzinnych w art. $436 \$ 4$ k.p.c. zwraca się uwagę, że stały mediator prowadzący mediacje rodzinne powinien mieć wiedze teoretyczną, w szczególności wykształcenie z zakresu psychologii, pedagogiki, socjologii lub prawa, oraz umiejętności praktyczne w zakresie prowadzenia mediacji w sprawach rodzinnych.

Wybór przez strony osoby mediatora związany jest z rodzajem mediacji. W przypadku mediacji prowadzonej na podstawie umowy to strony samodzielnie dokonują wyboru mediatora. W niektórych ośrodkach mediacyjnych mediacje rodzinne prowadzone są przez dwóch mediatorów równocześnie - kobietę i mężczyznę (tzw. ko-mediacja) ${ }^{35}$. W przypadku mediacji ze skierowania sądu, gdy strony nie wskazały osoby mediatora, sąd kieruje je w pierwszej kolejności do stałego mediatora mającego odpowiednią wiedzę w zakresie prowadzenia mediacji w sprawach danego rodzaju (art. $183^{9} \$ 1$ k.p.c.). Zgodnie $\mathrm{z}$ art. $183^{2} \$ 4$ k.p.c. stały mediator może odmówić prowadzenia mediacji tylko $\mathrm{z}$ ważnych powodów, o których zobowiązany jest poinformować strony oraz sąd, gdy to on skierował strony do mediacji. W przypadku sądowego skierowania stron do mediacji sąd wyznacza czas jej trwania na okres do trzech miesięcy. Z ważnych powodów lub na zgodny wniosek stron termin ten może zostać wydłużony, jeśli będzie to sprzyjać ugodowemu załatwieniu sprawy (art. $183^{10} \$ 1$ k.p.c.). Gdy strony zawrą ugodę przed mediatorem, na ich wniosek jest ona zatwierdzana przez sąd

35 A. Gójska, Mediacje rodzinne, dz. cyt., s. 159-162; M. Kaźmierczak, J. Kaźmierczak, Mediacja rodzinna..., dz. cyt., s. 49-52. 
(art. $183^{14} \$ 1$ k.p.c.). W przypadku gdy ugoda podlega wykonaniu w drodze egzekucji, sąd zatwierdza ją przez nadanie jej klauzuli wykonalności (art. $183^{14} \S 2$ k.p.c.). Zgodnie $\mathrm{z}$ art. $183^{15} \$ 1$ k.p.c. ugoda zawarta przed mediatorem, po jej zatwierdzeniu przez sąd, ma moc prawną ugody zawartej przed sądem. Ugoda, którą zatwierdzono przez nadanie jej klauzuli wykonalności, jest tytułem wykonawczym. Ugoda zawarta przed mediatorem, aby mogła być zatwierdzona przez sąd, musi spełniać kilka warunków: nie może być sprzeczna z prawem lub zasadami współżycia społecznego, nie może zmierzać do obejścia prawa, musi być zrozumiała oraz nie może zawierać sprzeczności (art. $183^{14} \S 3$ k.p.c.).

Mediacje prowadzone w sprawach rodzinnych bazują na podstawowych zasadach mediacji: dobrowolności uczestnictwa stron w mediacji, bezstronności i neutralności mediatora oraz poufności mediacji ${ }^{36}$. Zgodnie $z$ art. $183^{1} \$ 1$ k.p.c. mediacja jest dobrowolna. Każda ze stron może na każdym jej etapie zrezygnować z dalszego udziału. Strony mogą także odmówić podpisania ugody, nawet gdy wcześniej wyraziły zgodę na ustalone warunki porozumienia ${ }^{37}$. Zasada dobrowolności wiąże się także z możliwością zmiany mediatora przez strony, gdyż powinien on być zaakceptowany przez obie strony ${ }^{38}$. Zasady bezstronności i neutralności wiążą się z osobą mediatora. W myśl art. $183^{3}$ k.p.c. mediator powinien zachować bezstronność przy prowadzeniu mediacji oraz niezwłocznie ujawnić stronom okoliczności, które mogłyby wzbudzić wątpliwości co do jego bezstronności. Mediator nie może opowiadać się po żadnej ze stron, wyróżniać jednej strony czy być stronniczym. Nie powinien także oceniać stron. Mediator w równym stopniu powinien reprezentować interesy obu stron w dojściu do wzajemnie ich satysfakcjonującego porozumienia ${ }^{39}$. Neutralność mediatora wiąże się z kolei z przedmiotem sporu. Nie narzuca on stronom sposobu rozwiązania konfliktu i stoi na straży procedury, która sprzyja osiągnięciu porozumie$\mathrm{nia}^{40}$. Na drodze ku znalezieniu najlepszego rozwiązania sporu nie powinny zatem stanąć osobiste poglądy mediatora, jego przekonania czy uprzedzenia. Nie powinien mieć także interesu w jakimkolwiek szczególnym sposo-

\footnotetext{
36 P. Waszkiewicz, Zasady mediacji, w: Mediacje. Teoria i praktyka, dz. cyt., s. 92; Standard I, II, III, IV Standardy prowadzenia... .

37 P. Waszkiewicz, Zasady mediacji, dz. cyt., s. 93-94.

38 Standard I, Standardy prowadzenia..., dok. cyt.

39 P. Waszkiewicz, Zasady mediacji, dz. cyt., s. 96-97.

40 Standard II, Standardy prowadzenia..., dok. cyt.
} 
bie zakończeniu konfliktu między stronami ${ }^{41}$. Ostatnia z zasad odnosi się do braku jawności postępowania mediacyjnego (art. $183^{4} \S 1$ k.p.c). Zgodnie $\mathrm{z}$ art. $183^{4} \$ 2$ k.p.c. mediator, a także uczestnicy mediacji i inne osoby biorące udział w postępowaniu mediacyjnym zobowiązane są do zachowania w tajemnicy wszystkich faktów, o których dowiedziały się w trakcie mediacji. Mediator może zostać zwolniony z obowiązku tajemnicy tylko przez strony. Poufność mediacji wiąże się tym samym z zagwarantowaniem stronom poczucia bezpieczeństwa i przekonania, że sprawy poruszane w jej trakcie, często niezwykle trudne i bolesne dla stron oraz wywołujące wiele emocji, nie zostaną upublicznione ${ }^{42}$. Poufność mediacji wiąże się również $\mathrm{z}$ bezskutecznością powoływania się przez sądem na wzajemne ustępstwa czy propozycje ugodowe, które były składane w trakcie mediacji (art. $183^{4} \S 3$ k.p.c.) Przestrzeganie zasady poufności odnosi się także do przechowywania dokumentacji z mediacji ${ }^{43}$.

\section{Zakończenie}

Mediacje w sprawach rodzinnych są jednym ze zindywidualizowanych i dostosowanych do specyficznych potrzeb konkretnej rodziny sposobów rozwiązywania konfliktów. Umożliwiają one, przy wsparciu bezstronnej i neutralnej osoby trzeciej, znalezienie takiego rozwiązania sporu rodzinnego, które zadowala wszystkich członków rodziny i jest wzajemnie satysfakcjonujące. Uzyskane w toku wspólnych ustaleń porozumienie nie jest jedyną korzyścią z mediacji. Dzięki mediacji członkowie rodziny mają także szansę na zachowanie odpowiednich relacji w przyszłości, co jest szczególnie ważne zwłaszcza w sytuacji rozwodu, gdyż pozwala na efektywną współpracę rodziców w sprawach opieki nad dzieckiem i kontaktów dziecka z obojgiem rodziców także po ich rozstaniu. Mediacja pozwala rodzinie na uczestnictwo we wszystkich decyzjach związanych z rozwiązaniem konfliktu, ale wymaga również przyjęcia odpowiedzialności za wypracowane $\mathrm{w}$ trakcie mediacji ustalenia. Porozumienie zapewniające satysfakcję obu stronom konfliktu daje tym samym nadzieję na jego trwałość jako niena-

\footnotetext{
$41 \quad$ P. Waszkiewicz, Zasady mediacji, dz. cyt., s. 97.

42 P. Waszkiewicz, Zasady mediacji, dz. cyt., s. 100-101.

43 Standard IV, Standardy prowadzenia..., dok. cyt.
} 
rzucone z zewnątrz, ale jako wynik rodzinnej współpracy ukierunkowanej na wypracowanie wzajemnie korzystnego i dopasowanego do potrzeb danej rodziny sposobu rozwiązania sporu.

\section{Bibliografia}

Bargiel-Matusiewicz K., Negocjacje i mediacje, wyd. 2 zmienione, Warszawa 2010.

Centrum Mediacji Partners Polska, Rodzicielski Plan Wychowawczy. Porozumienie rozstajacych się rodziców, Warszawa 2009.

Cybulko A., Mediacja w sprawach rodzinnych, w: Mediacje. Teoria i praktyka, red. E. Gmurzyńska, R. Morek, Warszawa 2009, s. 193-200.

Czy tylko sąd rozstrzygnie w sporze? Mediacja i sądownictwo polubowne. Informator o alternatywnych sposobach rozwiązywania sporów, red. A. Rękas, Warszawa 2010.

Gójska A., Mediacja w sprawach rodzinnych. Stan prawny na 1 września 2011 r., Warszawa 2011.

Gójska A., Mediacje rodzinne, Warszawa 2014.

Gruca-Miąsik U., Negocjacje i mediacje w kręu pomocy, wychowania i prawa, Rzeszów 2011.

Kalisz A., Zienkiewicz A., Mediacja sądowa i pozasądowa. Zarys wykładu, Warszawa 2009.

Kaźmierczak M., Kaźmierczak J., Mediacja rodzinna. Praktyczny poradnik, Warszawa 2015.

Kordasiewicz S., Historyczna i międzynarodowa perspektywa mediacji, w: Mediacje. Teoria i praktyka, red. E. Gmurzyńska, R. Morek, Warszawa 2009, s. 31-50.

Michalak M., Mediacja a dziecko, w: Mediacja dla każdego, red. L. Mazowiecka, Warszawa 2010, s. 117-121.

Ministerstwo Sprawiedliwości, Postępowania $w$ sprawach rodzinnych $w$ sqdach powszechnych zakończone $w$ wyniku postępowania mediacyjnego w latach 2006-2017, http://isws.ms.gov.pl/pl/baza-statystyczna/opracowania-wieloletne/ (02.10.2018). 
Moore Ch., Mediacje. Praktyczne strategie rozwiązywania konfliktów, thum. A. Cybulko, M. Zieliński, Warszawa 2009.

Przybyła-Basista H., Mediacje rodzinne w konflikcie rozwodowym. Gotowość i opór małżonków a efektywność procesu mediacji, Katowice 2006.

Rekomendacja Nr R (98) 1 Komitetu Ministrów Rady Europy dla państw członkowskich na temat mediacji rodzinnej oraz Memorandum wyjaśniające (przyjęta przez Komitet Ministrów 21 stycznia 1998 roku na 616-tym spotkaniu wiceministrów, https://www.ms.gov.pl/pl/dzialalnosc/mediacje/publikacje-akty-prawne-statystyki/ (10.10.2018).

Standardy prowadzenia mediacji i postępowania mediatora, uchwalone przez Społeczna Rade do spraw Alternatywnych Metod Rozwiazywania Konfliktów i Sporów przy Ministrze Sprawiedliwości w dniu 26 czerwca 2006 r., https://www.ms.gov.pl/pl/dzialalnosc/mediacje/publikacje-akty -prawne-statystyki/ (10.10.2018).

Waszkiewicz P., Zasady mediacji, w: Mediacje. Teoria i praktyka, red. E. Gmurzyńska, R. Morek, Warszawa 2009, s. 91-103. 
